\title{
Challenges in the teaching of Cartography during the COVID- 19 pandemic: use of Minecraft in the remote classroom setting
}

\author{
Carla Cristina Reinaldo Gimenes de Sena ${ }^{\mathrm{a} *}$, Barbara Gomes Flaire Jordão ${ }^{\mathrm{b}}$ \\ a UNESP (Universidade Estadual Paulista [São Paulo State University]), 1st Author - carla.sena@unesp.br \\ b USP (Universidade de São Paulo [University of São Paulo]), 2nd Author-barbaraflaire@ hotmail.com \\ * Corresponding author
}

\begin{abstract}
The multi-tasking and technological phenomena of modern society form the basis for so-called active methodology options, which engage students through several different teaching strategies. Among these strategies is game-based learning, very appealing to the younger generation of students and with great didactic potential in the teaching of Cartography and Geography. With the increase in versions of games available on different platforms, their lower cost and the introduction of devices such as mobile telephones, smartphones, tablet computers and desk top computers into the school environment, it has been possible to introduce a sandbox-type game in the didactic approach to the teaching of Geography, which includes cartography content. The purpose of this article is to demonstrate the potential of a methodology based on use of the digital game Minecraft for the learning of cartographic concepts related to geographical themes in primary education during the period of social isolation, in which schools remained closed in Brazil, due to the advancing COVID-19 pandemic. This didactic concept was applied to 178 students at a private school in the city of Ribeirão Preto/SP [São Paulo] in the context of remote learning, between the months of October and November 2020. The outcomes were assessed based on the students' comprehension of the different viewpoints and the function and importance of scale in representations they created using Minecraft. The study demonstrated that, by "constructing" their representations, students could become the protagonists of their own learning process, connecting theoretical concepts to everyday practice and, thus, giving meaning to what they were being taught.
\end{abstract}

Keywords: Cartography teaching, pandemic, Minecraft, game-based learning.

\section{Introduction}

In the time between the first reported case of contamination by the SARS-CoV2 virus in Wuham, China, in December 2019, and the writing of this article, modern society has faced many challenges in the areas pertaining to the socioeconomic model in place in most countries.

In education, we have witnessed a break from classroom teaching models, wherein students have migrated to the remote learning environment. This improvised distance education has forced educators to urgently develop material and methodologies, in order to enable students to continue studying at home. The recording of video classes and live transmissions on several platforms and educational applications, among other tools, have become viable alternatives to ensure that children and youths do not miss the school year. In Brazil, remote learning was considered as an alternative from March 23, 2020, when classes were suspended and schools closed, making it necessary to re-adapt content and teaching methods.

The pandemic has forced education professionals to adopt the home office environment as an alternative, and they have had to adapt to this working model, which requires familiarity with digital tools and knowledge of methodologies in this context.

This scenario has led to issues that will require future analysis and assessment in order to comprehend how the implementation of remote learning has impacted education, considering the level of social inequality that has become acutely apparent, due to the difficulty that thousands of public school students in Brazil face in accessing the internet on a regular basis.

In this article, we present some of the challenges in the teaching of Cartography, in the context of Geography classes, during the period of social isolation imposed in 2020, in the city of Ribeirão Preto, located $350 \mathrm{~km}$ from São Paulo (Brazil), with the purpose of disseminating data that will assist in discussions and reflections on the main challenges and changes in education, due to COVID-19.

A descriptive and exploratory qualitative study was undertaken, divided into three stages: I) Bibliographical Revision; II) Practice of Cartography during the remote teaching of Geography, based on the application of activities using constructive games; III) Analyses and reflection on the outcomes of the experience.

\section{Technology and games in education}

We live in a society that is based on Information and Communication Technology (ICT). From this perspective, the "immediacy and universality in the propagation of certain modernizations" (SANTOS, 1997a, p. 29) means that personal and social development of people is determined, in large part, by their capacity to manage these technologies.

With the invention of the first computers, society incorporated a technological tool with great potential that 
has become ever more representative throughout the world. Currently, companies such as Intel, Google and Microsoft have progressively invested in the offer of educational technologies and courses for teachers by effectively including ICTs in everyday school life.

In 2013, the Maker culture and free technology labs (FabLabs) entered into partnerships with several primary schools in Brazil and abroad to develop teaching and learning processes based on knowledge of the functioning of technologies for problem solving. The high number of schools that have adopted remote learning during the pandemic has fast-tracked the incorporation of these resources into the school environment in a continuous manner, and not merely in the form of extracurricular activities. Altoé (2005) states that technology has led to a shift in educational paradigms, because it requires a new posture on the part of teachers and students, and a rethink of educational processes and school activities. These changes have been exacerbated during quarantine.

Among the challenges faced by teachers at this moment are the domination of technological tools, the search for and development of new teaching methodologies in the virtual environment, the creation of a work space and the maintenance of the study routine.

In addition to these challenges, we also have the necessity to ensure that students continue to learn and remain engaged. How is this done remotely?

With the expansion of access to mobile devices worldwide and the options available for smartphones, tablet computers and desk top computers, the potential of games for student engagement during the construction of their knowledge has grown. As an example of this, we have the game-based learning methodology, where content that is traditionally studied in school takes on an aspect of playablity, breaking with static teaching models and stimulating active learning, in which the student is the protagonist.

Recently, the entertainment industry has invested heavily in virtual games that simulate reality and/or stimulate interaction between players, in addition to presenting a vast array of options for players. Among these, we can highlight Open World, a style of game in which only minimal limitations are placed on players. Accordingly, players are free to move around in, and completely modify, the virtual world. Contrary to progression gameplay, the Open World modality emphasizes exploration and permits players to select the tasks they wish to perform (MOURA, 2014). For this article, we chose a software program based on construction, commonly allied to the term craft in its name, the most popular of which is Minecraft.

In the article How to Play with Maps, Ross Thorn (2019) presents a very promising overview of cartography in more recent videogames. Analyzing the characteristics of interactivity, immersion, incompleteness and use of entertaining maps, he emphasized that cartography in games helps players navigate and understand complex virtual geographies.
Although Thorn's research is not set in the school environment, from the data collected by the author and our experience as teachers using this type of tool, it is possible for us to state that the level of interaction that playability allows and the presence of cartographic representations are appealing to the young audience, given the ideal conditions, applied in the classroom. Furthermore, location-based games (LBGs) have been developed with increasingly complex maps in order to achieve the objectives of missions, such as Grand Theft Auto (GTA), Rockstar North and Need for Speed, by Electronic Arts.

In Brazil, the publication of the National Common Core Curriculum (Base Nacional Comum Curricular, BNCC) in 2018, the official document issued by the Ministry of Education (Ministério da Educação, MEC) that provides guidelines on the content and capacities to be developed throughout primary school education in Brazil, several common factors among different studies with regard to games and the cartographic content and the official curriculum can be noted.

[...] it is expected that, during their Primary Education, students will learn to dominate the reading and production of maps and graphs, as an introduction to cartographic literacy. Photographs, maps, diagrams, drawings, satellite images, audiovisual material and graphs, among other alternatives, are often used as curricular components. The more the diverse the work with language, the greater the repertoire constructed by the students, expanding the production of senses in their reading of the world. Understanding the peculiarities of each language, its potential and its limitations, leads to recognition of the products of these languages, not as truths, but as possibilities. (BRASIL, 2018, p. 361)

In this article, we present several remarks on the possibilities of the games during remote learning, especially Minecraft. This game was originally developed independently and today it belongs to Microsoft. It is a game with basic resources and broad creative possibilities. Based on constructions with 3D modeling blocks that imitate different elements in nature, the game maintains its videogame appeal, namely immersion, interest and interactivity, whilst also advancing several kinds of content present in the classroom.

In Brazil, it is possible to find positive experiences in the use of this game in the teaching of art, Portuguese language, history and mathematics (DIAS and ROSALEN, 2014; KNITTEL, et. al, 2017; SOUZA and MARQUES, 2019), in subject areas such as biodiversity, historical constructions and even geometry. In other countries, studies such as those by Iwahashi et. al (2019) and Agostinelli (2019) report considerable gains in the learning of Geography through the use of Minecraft.

The possibilities were such that, in 2016, Microsoft launched Minecraft: Education Edition, a version of the block game developed for use in the classroom, enabling 
teachers to have control over what happens in maps and the freedom to create an educational virtual environment in accordance with the subject matter to be covered and the age range.

Based on previous experience (SENA and JORDÃO, $2020 \mathrm{a} ; 2020 \mathrm{~b}$ ), in which use of this game in the classroom had positive outcomes with regard to the learning of basic concepts of cartography for more than 500 students aged 10 to 17 years, between 2016 and 2019, we investigated whether these outcomes have prevailed during remote learning, and whether Minecraft can be used as a teaching resource for Geography, even in the remote setting, in order to ensure that students feel engaged and motivated to learn, by encouraging their creativity, curiosity and geographic reasoning.case of multi-authorship, group them by firm or organization as shown in the title of these Guidelines.

\subsection{The challenges of teaching Cartography in Brazil: brief remarks}

Geography teaching, as stated herein, is facing a surprising transformation due to technologies and digital resources, which have changed everyday life and, consequently, the reality of education.

In order to interpret the reality and present it in a consistent manner, with the possibility of analysis, Geography has several visual resources, particularly maps. This set of instruments used for geography education, is actually an autonomous science, full of peculiarities, with a broad capacity for interpretation and processing of data. Harley (2005) states that cartographers not only represent the world, they actually construct it and, accordingly, maps need to be carefully studied. This power and its imaging potential make the production of maps almost an "innate skill of humanity" (RAISZ, 1969, p. 7).

Given its complexity, in the 1970s, cartographers from several countries started to study the process of cartographic communication, taking into account the dimensions of the map maker and the user, presenting factors that influence the production and consumption of maps. Thus, Cartography started to take into account map users, the messages they were transmitting and the efficiency of maps as a means of communication, appearing for the first time in the definitions of the International Cartographic Association (ICA):

[...] awareness that it involves the organization, presentation, communication and use of geoinformation, in a manner that may be visual, numerical or tactile, including all the processes of development after the preparation of data, as well as the study and use of maps or means of representation in all its forms. (ICA, 1991).

Meine (1978) summarizes the process of cartographic communication based on a reflection as a function of the following questions: WHAT? HOW? WHAT MEANS or EXPRESSIONS? AND FOR WHOM? For this author, Cartography is a science that covers theory and practice, and that involves scientific processes (such as generalization), as well as technical processes (drawing, reproduction, etc.).

Taylor (1991) shows concern with new forms of obtaining and disclosing cartographic information based on major technological advances and he revisits some of the issues raised by Meine (1978), while concluding with the following questions: WHEN? WHERE? WHY? and WITH WHAT RESULTS? Demonstrating that maps need to and can answer other questions.

Through technological evolution, Cartography began to present more wide-ranging definitions, including those presented by the ICA on its website, in 2003:

A map is a symbolized representation of geographic reality, representing selected features or characteristics, resulting from the creative effort of its author's execution of choices, and is designed for use when spatial relationships are of primary relevance. Cartography is the art, science and technology of making and using maps (ICA, 2003).

We call this entire process, from the research of data to the comprehension of maps, Cartography. We have been concerned with communication, but now also with how individuals conceive space through its representation, as presented by ICA in this manner, not limited merely to a technical procedure.

We believe that this characteristic, that of communicating, is important for studies that involve the teaching of Geography. Now, teachers need to regard maps as an interpretation of part of the world, infused with meanings and contexts to be addressed. Maps cannot be seen as static, exact or illustrative objects, but rather as part of a process of transmitting information constructed in a complex manner. For us, the role of the geography teacher underwent a paradigm shift when the theory of communication came to Cartography.

Accordingly, in Brazil, there is a growing area of study called School Cartography, which focuses on studying the learning of maps and learning through maps, mainly with works that are dedicated to discussing and proposing new methodologies and new techniques, based especially on the learning theories of Piaget and Vygotsky. This area has increased in importance by indicating that the process of acquiring specific knowledge for the domination of cartographic resources takes on a direction with differing degrees of complexity, from the development of laterality and the interpretation of more complex maps, to the conscientious use of the symbolic language of maps.

However, despite the promising paths and the efforts to introduce cartographic knowledge into regular school curricula, attentive to the plurality of the Brazilian reality, maps are still a challenge in these modern times, as the appropriation of this language remains a fragile process. Maybe this fragility can be extended to geographers in general, but, effectively, in Brazil it is linked to the training of Geography teachers and the instructional material used. 
In summary, Brazilian research has indicated that: I - Most teachers in the first years of primary education, as well as a considerable portion of those qualified to teach Geography specifically, have a poor level of proficiency in the field of cartographic language. II - The School Geographic Atlas is an underused resource; III - Tests and educational activities in the area of Geography contain few questions involving the interpretation of maps; IV Cartography content is concentrated in the sixth year of primary education in most official programs and didactic material for Geography; V - Maps are very often used for illustrative purposes and not as teaching resources in most didactic manuals in the area of Geography; and VI - the activities present somewhat of a discrepancy between students' real spaces and the cartographic space.

These issues have lead to a significant loss in the learning of Cartography, both at the primary and high school levels. Furthermore, this has compromised the development of geographic reasoning, an essential ability in the critical observation of space, problem solving and solution creation, which are often based on or connected to the representation of objects and spatial phenomena.

\section{The process of adapting remote learning to the use of Minecraft}

The SEB school is located in the district of Santa Cruz, in the city of Ribeirão Preto-SP, $350 \mathrm{~km}$ from the state capital, in the southeastern region of Brazil. According to the local city hall, the district has a wide variety of services and commerce, and is home to approximately $5.7 \%$ of the municipal population; the socioeconomic level is above the national average. This is a private school and, as such, it serves the wealthier residents of Ribeirão Preto.

At this school, the use of tablet computers was encouraged from 2015 , becoming mandatory as a means of delivering didactic material from 2017. In 2020, due to the forced implementation of remote learning, smartphones were also authorized as an alternative to tablet computers. The 178 participants in this survey (sixth-year students, aged between 10 and 12 years) possessed at least one of the aforementioned devices, while some also used videogames, desktop and notebook computers, and all had access to the internet.

During the pandemic, the challenges of engaging students in the learning of Cartography, within the context of geography classes, presented two complicating factors: (i) the content itself was quite challenging for students who had had little contact with maps in the first years of their education; and (ii) how to produce a map remotely, without the physical presence of the teacher to guide students in this construction and to invoke reflections during this activity? In the context of this school, contrary to most other Brazilian schools, there was the possibility of including the game Minecraft in order to overcome these gaps, thus presenting the content in the form of a leisure tool that students were already familiar with.

This activity was implemented in the second semester of the year, in line with the organization of the didactic material that includes Cartography at the end of the year, between October and November. This point is important, because after seven months of social isolation, most students had already dominated the digital tools used by the institution, thus significantly reducing the challenges in accessing the material and understanding the instructions presented by teachers.

Although Minecraft has an educational version, the common version of the game was used, considering that most of the students already had and played Minecraft out of school. Version 13.0 was chosen, as it enables the joint construction of the virtual space; in other words, several students could access what is called the "world" in the game and develop their projects in partnership. It was decided that students would start their constructions in the "flat world" option, which refers to an interface in which there is nothing previously constructed. Four classes of 40 minutes each, conducted over the Microsoft Teams Plataform, were necessary to develop the activity.

The sixth year Cartography curriculum begins by presenting the basic mapping elements traditionally taught to this age range (title, font, scale, orientation, key and projection), ensuring that students are clear on each of their functions. Considering the current context, the geography teacher gave an oral informative presentation, aided by slides, linking the use of these elements to the everyday lives of the students, including in the games used by them, illustrating the content covered.

In the next class, the focus was on the trajectory of cartography over time; as this content was not included in the students' didactic material, cartography was explained as a social construct, the purpose of presenting old maps and those of other societies was to expand the students' world view and to emphasize maps as a form of language. The class included a display of maps through slides and the discussion of what was being represented, how it was represented, to whom and why, in addition to reflecting on the necessity, or lack thereof, of the basic elements covered in the previous class.

Given the current moment, the students' input was of extreme importance. They were encouraged to think about the issues that involved the old maps and whether, based on what was seen, the map would reflect reality. Ninetyseven percent of the students achieved satisfactory performance, replying that it was a representation of space and that could vary from society to society. We emphasize one student's reply: "The map is not identical to reality, because the map could have a purpose for certain people and, accordingly, it will use material and symbols that these people will be able to understand." Meanwhile, another student stated that "the map cannot be reality because it is not a photo and, even if it were, everything changes all the time, and that is why it is a representation of the space at that moment and it shows what it wants to show."

A questionnaire was given to students in the next class, through the Mentimeter application, with the following questions: 1 - Have you ever heard of vertical and oblique views? What do you know about the scale of maps? 
With regard to the first question, 77\% did not know what they were, $20 \%$ managed to explain at least the vertical view and only $3 \%$ knew the two forms of map presentation.

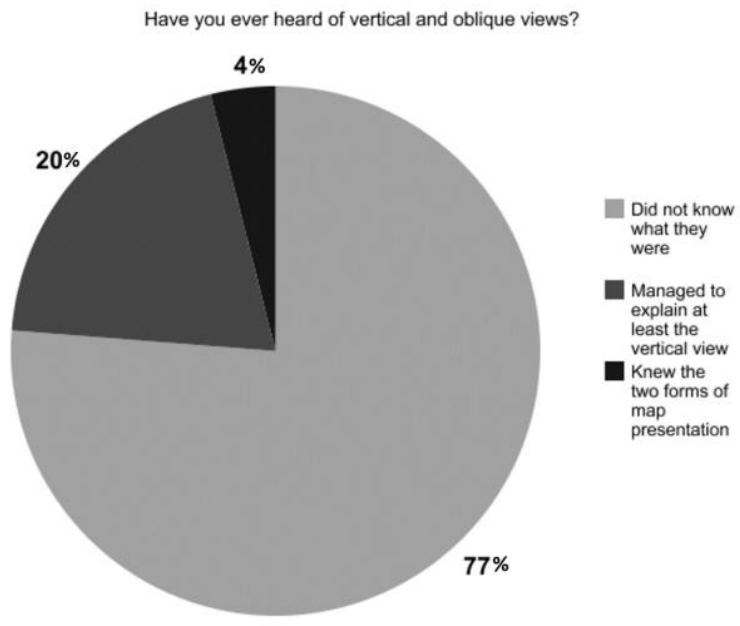

Graphic 1. Answers to question "Have you ever heard of vertical and oblique views?"

With regard to the second question, $96 \%$ of the students gave a satisfactory answer as to the definition of scale, very probably due to the first class in which this element was presented to students.
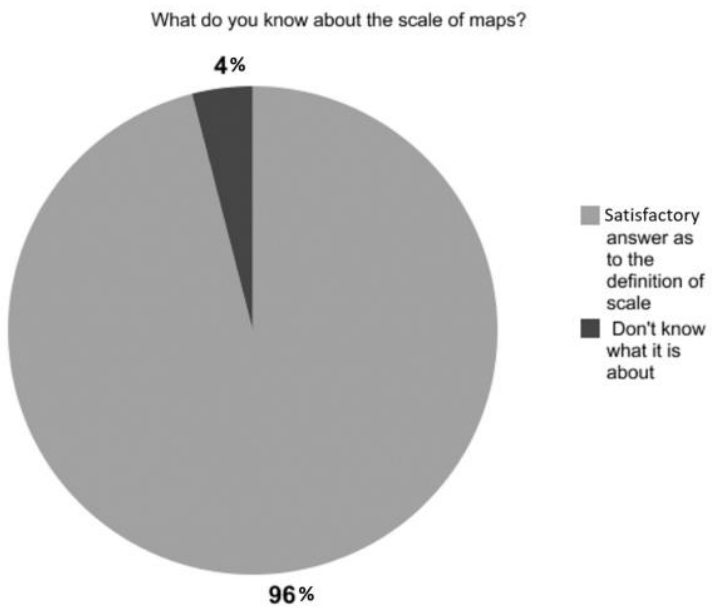

Graphic 2. Answers to question 2 "What do you know about the scale of maps?"

Supplementing the exercise, the teacher asked what the scale was for. What problems or solutions could arise from it? At this moment, the students could participate with their reflections. It could be noted from the input of the students that they were aware of the concept, but they could not understand the purpose of the importance of scale. There is an absence of reflection on this element. These questions provided the basis for the next stage and they were used as a parameter to analyze the acquisition of knowledge after the practical activity.

In the next class, the teacher proposed a challenge to the students. Students had to choose geography content taught during the school year and they would have a week to reproduce it in the Minecraft environment and present it to the rest of the class. The students were divided into groups of up to four people in order to undertake the project. In principle, the students did not relate the challenge to the content covered in the previous classes, but because it was a well-known game among the students, they were very excited.

The students started their presentations in the first week of November. Content including biomas and drainage basins, studied in the second and third quarters, respectively, predominated.

During their presentations, students were asked to show their projects in the vertical and oblique views. The issues of laterality, which was thought to have been resolved by this stage, needed to be reviewed, and was only explained to the first group, whose members were encouraged to understand the differences between the two views. Furthermore, the graphic symbolism of maps, present in the keys, was discussed and often it is related to the simplification of objects that exist in the mapped space, seen from the vertical viewpoint. (Figures 1 and 2).

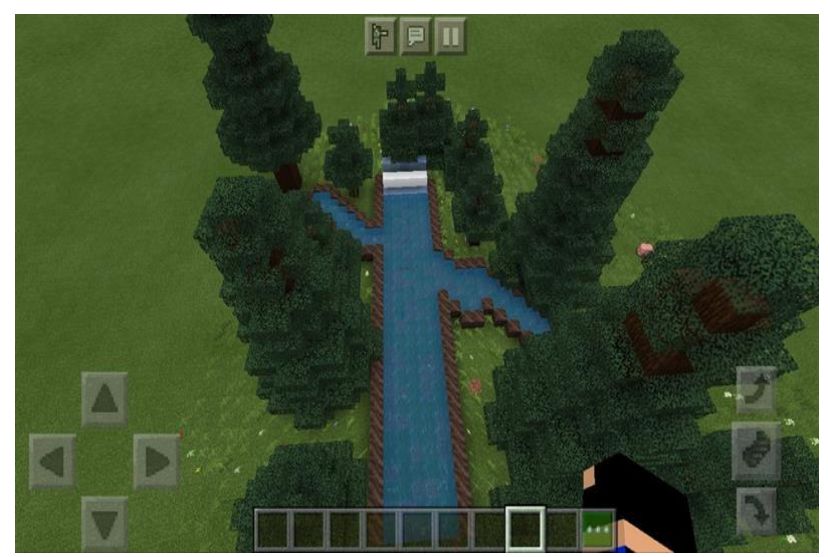

Figure 1: Oblique view of the project representing a Drainage Basin, constructed by group A.

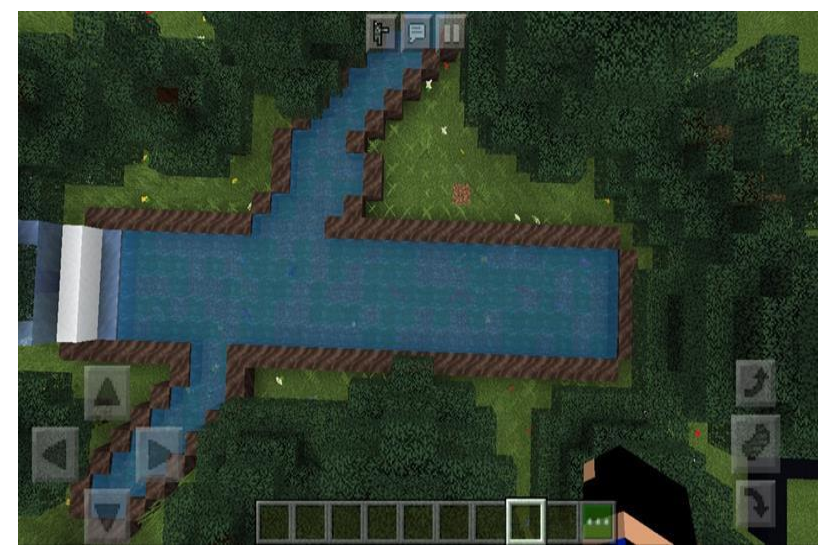

Figure 2: Vertical view of the project representing a Drainage Basin, constructed by group A.

The students were questioned about the level of detail of their project, by zooming in and zooming out. At this moment, the students were able to understand and apply scale. There was no significant difficulty in the use of different scales, which demonstrates comprehension of the 
concept of proportion and the relationship between the denominator of scale and the level of detail of the representation. Reduction and expansion of the environment (figures 3 and 4) in order to achieve the proposed objectives enabled the students to apply, in practice, the concept of a larger scale, represented by a smaller denominator with many details, and a smaller scale, with a larger denominator, enabling a broader view, but with a consequent loss of detail. (MENEZES and FERNANDES, 2013, p. 52)

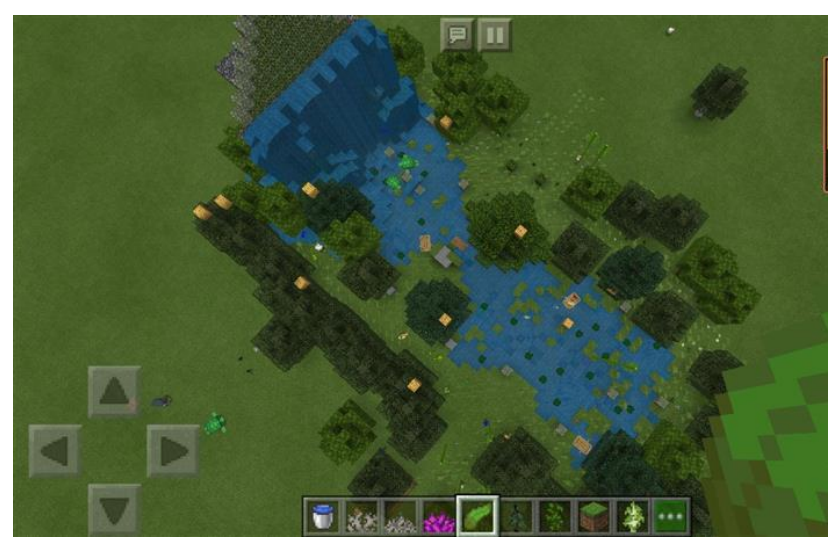

Figure 3: Representation of the bioma of the tropical forest, constructed by group B on a smaller scale.

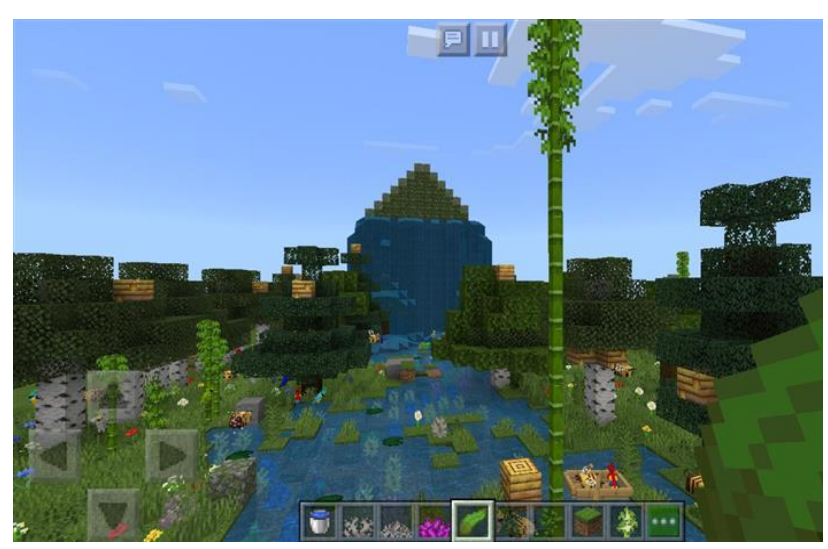

Figure 4: Representation of the bioma of the tropical forest, constructed by group B on a larger scale (application of zoom). Detail for the appearance of elements that it was not previously possible to view, due to the scale.

Concluding the didactic sequence, the students were asked about the production of the 3D model and the production of a map, based on their projects. Reflections on the selection of information, objectives and possibilities of Cartography concluded the discussions.

Motivated by their proximity with the game, the objective of constructing and presenting their projects to their classmates and the very playability of Minecraft, the students demonstrated significant interest and remained focused on concluding the project. We have observed significant gains for the teaching of Cartography, the extent that the students, even while abiding by social distancing norms, could construct their own representations and bring them into their everyday lives.
Accordingly, the game offered educational functionalities during the period of remote learning, equivalent to the experiences of classroom learning (SENA and JORDÃO, 2020), and it enabled supplementary cartography content to be introduced and effectively used, thus aggregating the value of the applicability and the logic in the use of this content.

\section{Final considerations}

Given the current trend of engaging students in the use of technology, the game promotes the development of the individual student's critical reasoning, agency, citizenship and leadership capacity, in addition to enabling them to put theory into practice in a virtual environment, thus giving purpose to what is learned in the classroom. We also have to consider the union between Cartography and other geographic content, which is essential to the development of geographic reasoning.

We know that not all schools will have access to the resources presented herein. Especially in Brazil, a country with so much social inequality, which tends to exclude students rather than implementing education without frontiers.

However, our objective here is to present an option that justifies the necessity for fair and egalitarian education for all. The use of a game, which requires internet access and equipment, but which presents positive outcomes for the teaching of Cartography within the context of Geography classes, considering that these sciences and languages are of extreme importance in today's world, as they are even being implemented in order to comprehend the evolution of the SARS-CoV2 virus worldwide, serving as a vector for social mobilization for changes in education.

When the virtual games are incorporated into teaching, a new communication format is established, which refers to the narratives in games and the immersion achieved in this environment, which is as recent and impacting as cinematographic language (ARANHA, 2004).

Games may instigate abilities in children, develop interest in areas not always regarded as attractive in other media or even be a driver for the study of all curricular components (BREDA, 2018).

Despite its apparent predisposition in dealing with the world around us, and that fact that it is a concrete science, School Geography has been developed by abstraction. The use of virtual games in the classroom re-emphasizes the relevance of entertaining learning, whilst enabling a broader dialogue with Cartography.

\section{References}

Agostinelli, M. Simulating Trade and Industry with Minecraft: Education Edition. 2019.

Altoé. A. O desenvolvimento da informática aplicada no Brasil. In: Altoé, A; Costa, M. L. F.; Teruya, T. K. (org). Educação e novas tecnologias. Formação de Professores - EAD nº 16. Maringá: EDUEM, 2005

Aranha. G. O processo de consolidação dos jogos eletrônicos como instrumento de comunicação e de 
construção de conhecimento. In. Cien. \& Cogn., 03, 21 62, 2004.

Brasil, MEC. Base Nacional Comum Curricular. Versão final. 2018.

Breda, T. V. Jogos geográficos na sala de aula. Curitiba. Appris, 2018.

Dias, N. F. e Rosalen, M. Minecraft: aprendendo mais com blocos In: Cadernos de Educação, v.13, n. 27, jul -dez. 59-78 - 2014.

Harley, B. Textos y contextos en la interpretación de los primeiros mapas. In: La Nueva Naturaleza de los mapas: Ensayos sobre la história de la cartografia. México: Fondo de Cultura Económica, 59-78, 2005.

International Cartographic Association. A strategic plan for the International Cartographic Association 20032011. Durban: ICA, 2003.

Iwahashi, J. Nishioka Y. Kawabata. D. Ando, A. Development of an online learning environment for geography and geology using Minecraft. Abstracts 29th International Cartographic Conference (ICC 2019), 1520 July 2019, Tokyo, Japan.

Knittel, T. Santana, L. Pereira, M E Menuzzi, M. Minecraft: Experiências de Sucesso dentro e fora da sala de aula. In: Anais do XVI SBGames - Curitiba - PR 789 - 795- Brazil, 2017.

Meine, K. H. Certain Aspects of Cartographic Communication in a System of Cartography as a Science. International Yearbook of Cartography - 102- 117 - nº 18 , 1978.

Menezes, P. M. L e Fernades, M. C. Roteiro de cartografia. Oficina de textos. São Paulo, 2013.

Moura, J. Saiba o que são games sandbox e os principais títulos do mercado. In Revista Techtudo. On line, 2014.

Prensky, M. Digital Natives, Digital Immigrants, Horizon. MCB University Press, Vol. 9 No. 5, October 2001.

Raisz, E. J. Cartografia geral. 2. ed. Rio de Janeiro: Científica, 1969.

Santos, M. Espaço e método. São Paulo: Nobel, 1997.

Schiavetto, S. Formas contemporâneas de relação entre capital e tecnicidade: estudo sobre a gênese de microprocessadores de licença proprietária e livre. Campinas: IFCH/Unicamp. Dissertação de Mestrado. 2014.

Sena, C. C. R. G. De; Jordão, B. G. F. Aprendizagem de cartografia baseada em jogos: a utilização do minecraft nas aulas de Geografia. In: Anais XI Colóquio de Cartografia para Crianças e Escolares. Banner. 2020a. https://wp.ufpel.edu.br/ccce/banners/

Sena, C. C. R. G. De; Jordão, B. G. F. The Possibility of Developing Geographic and Cartographic Education using Minecraft. In: Abstracts Central European Cartographic Conference and 68th German Cartography Congress - EuroCarto 2020, 21-25 September 2020b, Vienna, Austria (online).
Simielli, M. E. O mapa como meio de comunicaçãoe alfabetização cartográfica. In: Almeida, R. D. de (Org.) Cartografia Escolar. $2^{a}$ ed., 71-94, São Paulo: Contexto, 2010.

Souza, M. C. e Marques, P. H. M. Minecraft e inovação: estudo do desenvolvimento de um mindset criativo em oficinas com temáticas vindas dos jogos In: Anais do III Congresso de Inovação e Metodologias no Ensino Superior e I Encontro das Licenciaturas. Universidade Federal de Minas Gerais, 1 - 11, 2019.

Taylor, D. R. A Conceptual Basis for Cartography: new directions for the information era. Cartographica, vol.28, n 4, Canadá: University of Toronto Press, 1-8, 1991.

Thorn, R. How to Play with Maps. Master Thesis (Geographic Information Science and Cartography) In: University of Wisconsin-Madison, 2018. 